OPEN ACCESS

Edited by:

Emanuela Marcenaro,

Università di Genova, Italy

Reviewed by:

Christine Susanne Falk,

Hannover Medical School, Germany

Nicholas D. Huntington,

Walter and Eliza Hall Institute of

Medical Research, Australia

*Correspondence:

Giovanni Bernardini

giovanni.bernardini@uniroma1.it

Specialty section:

This article was submitted

to NK Cell Biology,

a section of the journal

Frontiers in Immunology

Received: 31 July 2016 Accepted: 21 September 2016 Published: 06 October 2016

Citation:

Bernardini G, Antonangeli F, Bonanni $V$ and Santoni A (2016)

Dysregulation of Chemokine/

Chemokine Receptor Axes and NK

Cell Tissue Localization

during Diseases.

Front. Immunol. 7:402.

doi: 10.3389/fimmu.2016.00402

\section{Dysregulation of Chemokine/ Chemokine Receptor Axes and NK Cell Tissue Localization during Diseases}

\author{
Giovanni Bernardini ${ }^{1,2 *}$, Fabrizio Antonangeli ${ }^{1}$, Valentina Bonanni ${ }^{1}$ and Angela Santoni ${ }^{2,3}$ \\ ${ }^{1}$ Department of Molecular Medicine, Sapienza University, Rome, Italy, ${ }^{2}$ IRCCS NEUROMED - Mediterranean Neurological \\ Institute, Isernia, Italy, ${ }^{3}$ Department of Molecular Medicine, Istituto Pasteur-Fondazione Cenci Bolognetti, Rome, Italy
}

Chemokines are small chemotactic molecules that play key roles in physiological and pathological conditions. Upon signaling via their specific receptors, chemokines regulate tissue mobilization and trafficking of a wide array of immune cells, including natural killer (NK) cells. Current research is focused on analyzing changes in chemokine/chemokine receptor expression during various diseases to interfere with pathological trafficking of cells or to recruit selected cell types to specific tissues. NK cells are a heterogeneous lymphocyte population comprising several subsets endowed with distinct functional properties and mainly representing distinct stages of a linear development process. Because of their different functional potential, the type of subset that accumulates in a tissue drives the final outcome of NK cell-regulated immune response, leading to either protection or pathology. Correspondingly, chemokine receptors, including CXCR4, CXCR3, and $\mathrm{CX}_{3} \mathrm{CR} 1$, are differentially expressed by NK cell subsets, and their expression levels can be modulated during NK cell activation. At first, this review will summarize the current knowledge on the contribution of chemokines to the localization and generation of NK cell subsets in homeostasis. How an inappropriate chemotactic response can lead to pathology and how chemokine targeting can therapeutically affect tissue recruitment/ localization of distinct NK cell subsets will also be discussed.

Keywords: chemokine receptors, CXCR4, CXCR3, NK cell subsets, multiple sclerosis, multiple myeloma, crossinhibition, migration

\section{INTRODUCTION}

Natural killer (NK) cells are innate lymphocytes that play a key role in the immune response to tumors and infections through their ability to kill transformed or infected cells and to produce immunoregulatory cytokines and chemokines. Activation of NK cell effector functions can be achieved through a complex integration of inhibitory and activation signals provided by membrane expressed receptors and/or through cytokine stimulation (1).

Natural killer cells are widely distributed into different tissues such as the bone marrow (BM), liver, thymus, lymph node, and uterus, thus contributing to immune surveillance in homeostasis, and can be further recruited into tissues in pathological conditions $(2,3)$. While tissue-resident NK cells have been identified in uterus, liver, and skin, conventional NK cells continuously traffic 
and localize into tissue through a combination of stimuli able to promote their mobilization from storage compartments to blood circulation and their entry and retention into tissue (4-6).

Chemokines are a family of more than 50 small proteins, mostly secreted, that accomplish their function by interacting with heterotrimeric G protein-coupled receptors (GPCR). Chemokine binding promotes a conformational change in the receptor, triggering intracellular signals that drive cell polarization, migration, and adhesion, thus resulting in the induction of leukocyte trafficking and homing (3). Besides leukocyte chemotaxis, chemokines can affect a number of other leukocyte functions and are recognized as important regulators of the immune response (3). Chemokines may be grouped according to their modality of expression and function, as inflammatory or homeostatic (7).

\section{CHEMOKINE RECEPTOR EXPRESSION ON NK CELL SUBSETS}

A number of evidence indicates that the differential functional properties underlying NK cell-mediated protective effect in pathological conditions can be attributed to distinct NK cell populations endowed with distinct expression patterns of activating and inhibitory as well as homing receptors. Two major subsets of mature NK cells were identified in human peripheral blood with respect to the neural cell adhesion molecule CD56 and the low affinity receptor for IgG, Fc $\gamma$ RIII CD16. The CD $56^{\text {high }} \mathrm{CD} 16^{\text {low }}$ subset accounts for around $10 \%$ of circulating CD56 $6^{+} \mathrm{NK}$ cells and exerts immunomodulatory effects producing large amount of cytokines such as IFN $\gamma$ in response to activation, whereas CD56 ${ }^{\text {low }} \mathrm{CD} 16^{\text {high }}$ cells are the major cytotoxic population representing the majority of circulating $\mathrm{CD} 56^{+} \mathrm{NK}$ cells [for a review on human NK subsets, see Ref. (8)]. Although the exact relationship between these NK cell subsets still remains unclear, evidence suggest that $\mathrm{CD} 56^{\text {low }} \mathrm{NK}$ cells originate from CD56 ${ }^{\text {high }}$ NK cells (9-12).

Natural killer cell subsets display a differential pattern of chemokine receptor expression (Figure 1). CD56 $6^{\text {high }}$ NK cells are targeted to lymph nodes via CCR7, preferentially express CXCR3 and have higher CXCR4 expression levels as compared with CD56 ${ }^{\text {low }}$ cells. CD56 ${ }^{\text {low }}$ NK cells uniquely express CXCR1, ChemR23, and $\mathrm{CX}_{3} \mathrm{CR} 1$ (Figure 1) (see Table 1 for a list of ligands of chemoattractant receptors expressed by human and mouse NK cell subsets) (13-18). More recently, a new CD56 ${ }^{\text {low }} \mathrm{CD} 16^{\text {low }}$ subset has been identified and found to be prominent in the BM of healthy pediatric donors, to display potent killing and IFN $\gamma$ producing capacity, and to expresses higher levels of CXCR4 and

\section{Mouse:}
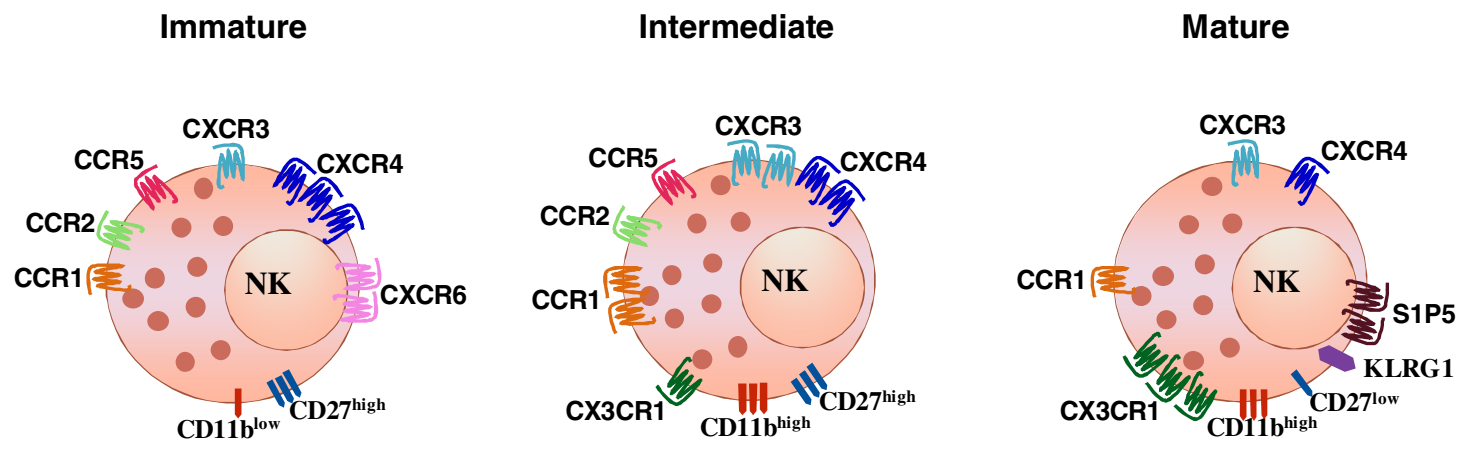

\section{Human:}
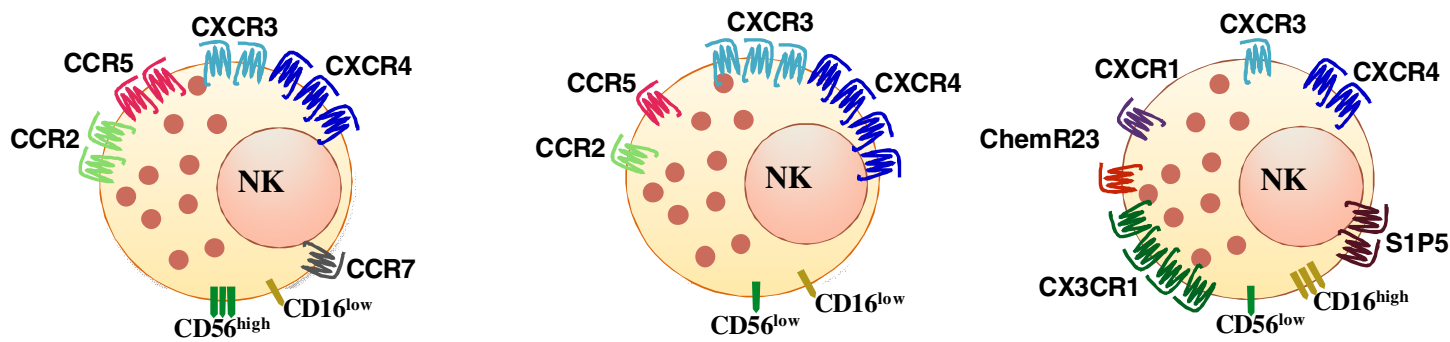

FIGURE 1 | Differential chemoattractant receptor expression by NK cell subsets in human and mouse. 
TABLE 1 | Chemokine receptor expression by NK cells and their respective ligands.

\begin{tabular}{|c|c|}
\hline Chemokine receptor & Chemokine ligand \\
\hline CCR1 & $\begin{array}{l}\text { CCL3/MIP-1 } \alpha, \text { CCL5/RANTES, CCL7/MCP-3, } \\
\text { CCL9/CCL10/MIP-1 } \gamma \text {, CCL14/HCC-1, CCL15/ } \\
\text { HCC-2, CCL16/HCC-4, CCL23/MPIF-1 }\end{array}$ \\
\hline CCR2 & $\begin{array}{l}\text { CCL2/MCP-1, CCL7/MCP-3, CCL12, } \\
\text { CCL13/MCP-4, CCL16/HCC-4 }\end{array}$ \\
\hline CCR5 & $\begin{array}{l}\text { CCL3/MIP-1 } \alpha, \text { CCL4/MIP-1 } \beta, \text { CCL5/RANTES, } \\
\text { CCL8/MCP-2, CCL14/HCC-1 }\end{array}$ \\
\hline CCR7 & CCL19/MIP-3ß/ELC, CCL21/SLC \\
\hline CXCR1 & CXCL8/IL-8 \\
\hline CXCR3 & CXCL9/Mig, CXCL10/IP-10, CXCL11/I-TAC \\
\hline CXCR4 & CXCL12/SDF-1 \\
\hline CXCR6 & CXCL16/SR-PSOX \\
\hline $\mathrm{CX}_{3} \mathrm{CR} 1$ & CX3CL1/fractalkine \\
\hline Chemoattractant receptors & Ligand \\
\hline S1P5 & S1P \\
\hline ChemR23, CCRL2 & Chemerin \\
\hline
\end{tabular}

The previous chemokine name follows the one currently used.

CXCR3 compared with the other subsets (17). In addition, other subsets related to NK cell maturation, including cells coexpressing CD57, a member of the glucuronyl-transferase gene family or the L-selectin within the CD56 $6^{\text {low }} \mathrm{NK}$ cells are currently active field of investigation (19-21).

Mouse NK cells do not express the murine ortholog of CD56, but four different developmentally related subsets have been identified on the basis of the expression levels of the integrin chain CD11b and of a member of the TNF receptor superfamily, CD27: $\mathrm{CD} 11 \mathrm{~b}^{\text {low }} \mathrm{CD} 27^{\text {low }}, \mathrm{CD} 11 \mathrm{~b}^{\text {low }} \mathrm{CD} 27^{\text {high }}, \mathrm{CD} 11 \mathrm{~b}^{\text {high }} \mathrm{CD} 27^{\text {high }}$, and $\mathrm{CD} 11 \mathrm{~b}^{\text {high }} \mathrm{CD} 27^{\text {low }}(22,23)$. The inhibitory receptor KLRG1 is acquired by the most mature subset and identifies NK cells with reduced effector functions (24). KLRG1 coexpression with the chemokine receptor $\mathrm{CX}_{3} \mathrm{CR}$ identifies an even later maturation stage with unique functional properties (25). Likewise, other NK cell subsets can be defined according to the expression of selected chemokine receptors: the prevalent expression of CXCR3 on CD56 $6^{\text {high }}$ was related to expression of the receptor on mouse $\mathrm{CD} 27^{\text {high }} \mathrm{NK}$ cells and more in general to stronger proliferative and cytokine production capacity $(26,27)$. In addition, CXCR6 was shown to identify an NK cell population resident in liver displaying in humans a $\mathrm{CD} 56^{\text {high }} \mathrm{CD} 16^{-} \mathrm{CD} 57^{-}$phenotype, and expressing TRAIL in diseased liver, and in the mouse a DX5-TRAIL ${ }^{+}$phenotype $(28,29)$.

\section{CHEMOKINE RECEPTOR INTERPLAY FOR EFFICIENT MIGRATION IN COMPLEX CHEMOTACTIC ENVIRONMENT}

Leukocytes express multiple chemokine receptors not only to robustly and promptly infiltrate tissues upon activation but also to navigate through the network provided by multiple competing chemotactic gradients perceived into tissue. Indeed, discrimination of a dominant chemoattractant is required to localize in the correct microenvironment and/or to make a decision on whether to stay or to leave a tissue $(30,31)$. The ability to preferentially respond to selected chemoattractants was at first demonstrated in neutrophils and was postulated to require heterologous receptor desensitization that is the transinhibition of a chemokine receptor resulting from the activation of second messenger-dependent kinases by a dominant chemoattractant receptor (32-34). In this regard, triggering $\mathrm{CXCR} 2$ by $\mathrm{KC}$ was shown to be required for neutrophil egress from the BM not only by promoting neutrophil migration but also by inhibiting CXCR4-mediated BM retention (35). Afterward, our group showed that CXCR4 heterologous desensitization is also associated with NK cell egress from BM into circulation $(36,37)$. On the other hand, the sphingophospholipid chemoattractant sphingosine-1-phosphate (S1P) promotes NK cell egress from BM under steady state without inducing CXCR4 heterologous desensitization (38). CX3CL1, a ligand for $\mathrm{CX}_{3} \mathrm{CR} 1$ constitutively expressed in BM, acts similarly on a small highly differentiated subset which poorly expresses CXCR4 $(25,39)$. While homeostatic chemokines may be sufficient for NK cell egress under steady state, heterologous receptor desensitization could be a mechanism to rapidly switch NK cell responsiveness promoted by inflammatory chemokines, to promptly facilitate BM NK cell availability in circulation.

Besides desensitization, CXCR4-mediated transinhibition can occur through other mechanisms, including receptor heterodimerization and $G$ protein scavenging (40). In regard to heterodimerization, it is becoming increasingly clear that receptor dimers are constitutively formed, and that ligand binding to one receptor can reorganize receptor complexes thus affecting different aspects of the associated chemokine receptor activity, including ligand affinity, the activated signaling cascades, and the receptor internalization (41-43). For example, CXCR3/CXCR4heterodimerization was shown to reduce the binding affinity of CXCR4 for its ligand (44).

Apart from the mechanism involved, cross-regulation promoted by CXCR3 was shown to be relevant in several pathological conditions in mouse disease models. For example, O'Boyle and coworkers demonstrated CXCR4 and CCR5 inhibition on T cells by using a mimetic of CXCL10, a CXCR3 ligand. The use of this mimetic in a humanized mouse air-pouch model demonstrated reduced trafficking of $\mathrm{T}$ cells toward synovial fluids from patients with active rheumatoid arthritis, indicating that the triggering of a single chemokine receptor can control the immune response in chronic inflammatory conditions where CXCL12 is produced at high levels $(45,46)$. More recently, our observations in a mouse model of multiple myeloma led us to hypothesize that increased expression of CXCR3 ligands in the tumor BM microenvironment constitutes a new mechanism to avoid tumor infiltration by NK cells: ligand-induced CXCR3 activation on KLRG1- NK cells resulted in cross-desensitization of CXCR4 that together with the coincident down-modulation of CXCL12 protein levels promotes NK cell egress from BM into blood circulation. The final outcome of this process is the reduction of the localization of this subset at the tumor site (39). On the other hand, when studying human plasmacytoid dendritic cells (pDC), a positive cooperative interaction was observed between the two receptors (47). This observation, together with a consistent adjacent expression of 
CXCL12 with CXCR3 ligands in human tissues, led the authors to hypothesize that the cooperation between CXCR3 ligands and CXCL12 controls the tissue recruitment of pDCs.

Considering the highlighted importance of CXCR3/CXCR4 interplay, hereafter we will document the critical role of CXCR3 and of CXCR4 receptor/ligand axes in the regulation of NK cellmediated function in pathologies (summarized in Table 2).

\section{CXCR4 RECEPTOR/LIGAND AXIS}

CXCL12 displays a constitutive but restricted expression pattern in situ, with selective expression by CXCL12 abundant reticular (CAR) cells and osteoblasts in BM, by subpopulations of neuronal and endothelial cells in the brain, by dermal endothelial cells, and by invading trophoblast cells and lymph node high endothelial venules (48-54). Correspondingly, CXCR4/CXCL12 axis was reported to regulate $\mathrm{NK}$ cell functions in several physiological processes. It was shown that CXCL12 regulates the positioning in the BM of selected NK cell subsets at various stages of maturation; in addition, during pregnancy, human peripheral blood CD56 ${ }^{\text {high }} \mathrm{CD} 16^{-} \mathrm{NK}$ cells can be recruited by CXCL12 and migrate to the uterus $(36,48)$.

Considering the key role of CXCL12 in the localization of NK cells in BM, subversion of the CXCR4/CXCL12 axis has been hypothesized to represent a mechanism of immune evasion from NK-mediated immune surveillance in neuroblastoma and multiple myeloma $(39,55)$. TGF- $\beta 1$ produced by neuroblastoma cell lines was shown to upregulate the surface expression of CXCR4 and CXCR3 on both CD56 $6^{\text {high }}$ and CD56 $6^{\text {low }}$ NK cells, while it downregulated $\mathrm{CX}_{3} \mathrm{CR} 1$ in the $\mathrm{CD} 56^{\text {low }}$ subset. Increased CXCR3 and reduced $\mathrm{CX}_{3} \mathrm{CR} 1$ expression was observed also in peripheral blood NK cells of stage 4 neuroblastoma patients, and it may represent an attempt to avoid NK cell cytolytic subset recruitment to the tumor site, while promoting the enrichment of immature and poorly cytotoxic CD56 ${ }^{\text {high }}$ subset in tumor leukocyte infiltrates $(55,56)$. Similarly, accumulation of CD $56^{\text {high }}$ NK cells was shown to occur in several tumors and may be related to the responsiveness of this subset to a combination of tissue-expressed chemokines: by analyzing the chemokine expression pattern of various normal solid tissues, Carrega and coworkers documented that some tissues are clearly oriented to recruit CD56 ${ }^{\text {high }}$ cells when CXCL12 is coexpressed with other chemokines (LN, colorectal, stomach, and liver tissues), while anatomic compartments with the lowest proportion of CD56 $6^{\text {high }}$ within NK cells (lung and breast tissues) display a chemokine expression profile favoring CD56 ${ }^{\text {low }} \mathrm{NK}$ cell recruitment (57). Similarly, decreased levels of CXCL12 in BM plasma samples from a cohort of patients with active multiple myeloma as compared with a premalignant stage support the hypothesis of a reduced NK cell surveillance based on reduced BM recruitment (39).

The key role of CXCR4 expression for NK cell homeostasis is also highlighted by genetic defects responsible for altered or lost CXCR4 function. For example, a more abundant proportion of circulating $\mathrm{GPI}^{-} \mathrm{CD} 56^{\text {high }} \mathrm{NK}$ cells in paroxysmal nocturnal hemoglobinuria patients, a disease caused by dampened biosynthesis of glycosylphosphatidylinositol (GPI)-linked protein, was associated with reduced responsiveness of this population to the CXCR4 ligand CXCL12 $(58,59)$. In addition, deficiency of the transcription factor GATA2 is characterized by several hematological and non-hematological abnormalities among which NK cell cytopenia, with almost complete absence of circulating CD56 ${ }^{\text {high }}$ subset (60). Interestingly, CD56 ${ }^{\text {low }} \mathrm{NK}$ cells display reduced CXCR4 surface expression levels and reduced chemotaxis to CXCL12 that was attributed decreased expression of filamin A and $\beta$-arrestin-1, two proteins regulating CXCR4 cell surface expression and endocytosis (61-63). On the other hand,

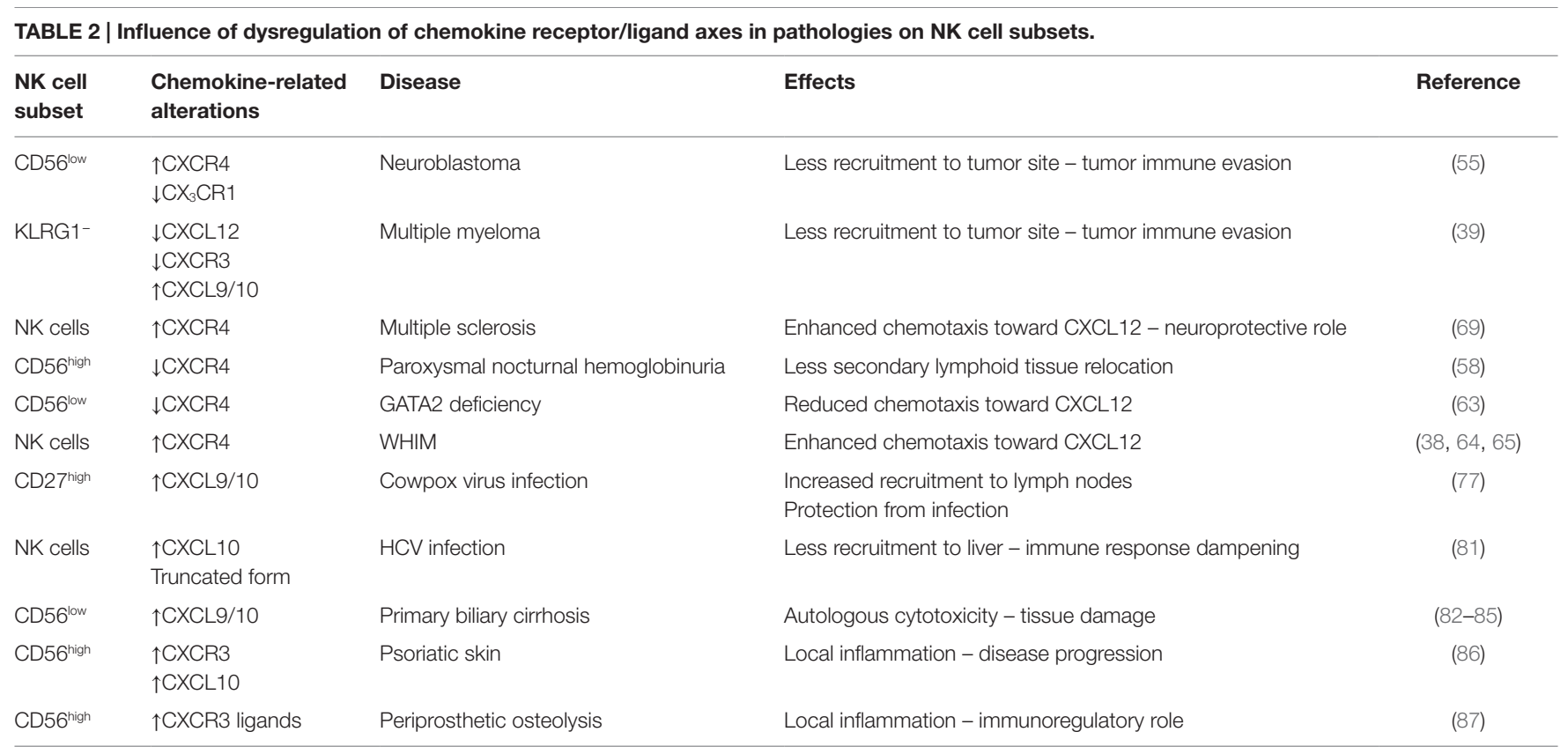

$\uparrow$ indicates up-modulation/increase frequency and $\downarrow$ indicates down-modulation/reduced frequency. 
NK cells from patients affected by warts, hypogammaglobulinemia, infections, and myelokathexis (WHIM) syndrome display enhanced responsiveness to CXCL12 $(38,64,65)$. Similarly, NK cells from mice displaying the most common mutation of the CXCR4 gene associated with WHIM syndrome show enhanced migration to CXCL12 that is linked to impaired CXCR4 desensitization and internalization after CXCL12 stimulation. Possibly for this reason, NK cell distribution is altered, with CD11b $\mathrm{b}^{\text {low }}$ and $\mathrm{CD} 11 \mathrm{~b}^{\text {high }} \mathrm{CD} 27^{\text {high }} \mathrm{NK}$ cells accumulating in the BM.

Although CXCR4 mutation in WHIM syndrome was not associated with any NK cell-related disease, a selective defect of CXCR4 internalization after CXCL12 binding underlies a new rare immune deficiency documented in two cases of disseminated Mycobacterium avium infection, where a marked reduction in the number of circulating NK cells as well as neutrophils and B cells was observed (66).

An altered pattern of CXCL12 expression in brain has been reported in multiple sclerosis $(67,68)$, suggesting the involvement of the CXCR4/CXCL12 axis in the leukocyte infiltration that characterizes this pathology. In this regard, while the interference with CXCR4/CXCL12 axis often leads to reduced NK cell protection in pathological conditions, Serrano-Pertierra and colleagues have found increased NK cell chemotaxis in response to CXCL12 in multiple sclerosis patients in the remitting phase and in clinically isolated syndrome patients with respect to relapsing multiple sclerosis patients and healthy controls. This finding has been associated with higher frequencies of NK cells expressing CXCR4 in the blood of the former patients' cohorts (69). The enhanced NK cell migration in patients with a less active disease course supports the idea of a neuroprotective role for NK cells in multiple sclerosis (70). Unfortunately, NK cells have been studied as a whole, and the authors agree it would be of interest to analyze NK cell subsets, also considering that the size of the circulating CD $56^{\text {high }} \mathrm{NK}$ cell pool is significantly associated with clinical remissions and that expansion of this population is associated with amelioration of diseases in response to therapy (71-75).

\section{CXCR3 RECEPTOR/LIGAND AXES}

CXCR3 ligands are expressed at low levels in homeostatic conditions, but their expression can be upregulated in both the hematopoietic and non-hematopoietic compartment by IFN- $\gamma$ and some related cytokines. Several studies in humans and mice reveal that NK cells can promote adaptive immune response by modulating dendritic cell (DC) function and T helper cell polarization (76). This important function is linked to CXCR3-mediated NK cell recruitment into draining lymph node in several conditions. In mouse, in accordance with higher and preferential expression levels of CXCR3, the NK cell population mostly affected by CXCR3 function is the $\mathrm{CD} 27^{\text {high }}$ subset that colonizes draining LN following DC vaccination, cowpox virus infection, and during tumor growth $(77,78)$. Several studies have correlated high numbers of tumor-infiltrating NK cells with a good prognosis for cancer patients and with tumor cell clearance in mouse tumor models. This has been related to the IFN- $\gamma$ promotion of CXCL9 and CXCL10 production by tumor-infiltrating leukocytes, leading to the CXCR3-mediated recruitment of mouse CD27 high NK cells, the population of NK cells with the higher functional potential (79).

The influence of CXCR3-CXCL10 axis on NK cell function was documented also in human pathologies. Upregulation of CXCR3 ligands in multiple myeloma patients with active disease corresponded to marked down-modulation of CXCR3 expression levels by BM NK cells, an event that was linked to reduction of NK cell localization in the BM in multiple myeloma-bearing mice. In addition, high CXCL9 and CXCL10 serum levels were associated with several established prognostic parameters and predicted poor overall survival $(39,80)$.

CXCL10/CXCR3 axis is involved in hepatic trafficking of NK cells, which also represent an important component of the intrahepatic lymphocyte pool and has been implicated in the pathogenesis of chronic hepatitis $\mathrm{C}$ virus (HCV) infection. The $\mathrm{CD} 6^{\text {high }} \mathrm{CXCR}^{+} \mathrm{NK}$ cells display the strongest activity against hepatic stellate cells, thus regulating liver fibrosis. Although expanded in $\mathrm{HCV}$-infected patients, the $\mathrm{CD} 56^{\text {high }} \mathrm{CXCR} 3^{+} \mathrm{NK}$ cell subset display impaired functions that may be linked to $\mathrm{HCV}$-associated liver fibrosis (27). Elevated levels of CXCL10 were found in serum of patients and were predictive of the failure to respond to HCV therapy. Nevertheless, in a recent study, it has been reported that CXCL10 in the serum of HCV patients may not be biologically active, representing a truncated form that can bind to CXCR3 without signaling. In the presence of higher levels of this CXCL10 antagonist, NK cells might fail to migrate to the infected liver and accumulate instead in the peripheral circulation (81).

Chemokines play an important role in destruction of the biliary tract (82) by recruiting cells of the immune system, including NK cells. As such, liver NK cells have been reported to express the chemokine receptors $\mathrm{CX}_{3} \mathrm{CR} 1$ and CXCR3 (83). Among the principal chemokines involved in hepatic immune cell migration, CXCL9 and CXCL10 are both increased in serum of patients with primary biliary cirrhosis (PBC) compared with normal individuals and are preferentially expressed in the portal areas, corresponding to $\mathrm{CD} 56^{\text {low }} \mathrm{CD} 16^{+} \mathrm{NK}$ cell liver infiltration increased numbers of $\mathrm{CD}^{+} 6^{+}$cells located around the destroyed small bile ducts $(84,85)$.

Several reports documented that CD56 ${ }^{\text {high }}$ NK cells also infiltrate inflamed skin in a CXCL10-dependent fashion. Ottaviani et al. have shown that psoriatic keratinocytes display an enhanced capacity to produce CXCL10, and CD $56^{\text {high }} \mathrm{CD} 16^{-} \mathrm{NK}$ cells showed an upregulation of CXCR3, in comparison to $\mathrm{CD} 56^{\text {low }} \mathrm{CD} 16^{+} \mathrm{NK}$ cells (86). CD56 ${ }^{\text {high }} \mathrm{CXCR} 3^{+} \mathrm{CCR} 5^{+}$cells produced IFN $\gamma$ after IL2 stimulation that in turn potentiates activation of keratinocytes and upregulates HLA class-I. These findings would suggest that $\mathrm{CD} 6^{+} \mathrm{NK}$ cells are recruited in psoriatic skin through a mechanism involving the CXCL10/CXCR3 axes and that, once in the skin, they may contribute to the disease progression by inducing local inflammation and amplifying $\mathrm{T}$ cell autoimmune reactivity.

Similar to psoriatic skin-infiltrating NK cells, NK cells in the synovial tissue of osteoarthritis patients are CCR $5^{+} \mathrm{CXCR} 3^{+}$. High levels of CXCR3 and CCR5 ligands present in synovial fluids after revision surgery, as well as evidence of particleinduced chemokine production by macrophages (87), suggest a 
mechanism for recruitment of a subset functionally corresponding to $\mathrm{CD} 56^{\text {high }} \mathrm{CD} 16^{-} \mathrm{NK}$ cells during periprosthetic osteolysis. The majority of synovial tissue-infiltrating NK cells express a combination of surface receptors consistent with a non-cytotoxic phenotype similar to blood.

\section{CONCLUSION}

The correct localization of NK cells into tissues has a fundamental role in several aspects of NK cell-mediated immune responses in vivo. Thus, identification of the key mediators regulating $\mathrm{NK}$ cell tissue recruitment is a critical step in the optimization of current cancer immunotherapy protocols or in the treatment of inflammatory diseases.

When NK cell tissue accumulation is important, the therapeutic enhancement of expression of selected chemokines that attract NK cells specifically is a valuable approach to increase the penetration and/or local activation and differentiation of NK cells at the tumor site. Ectopic expression of chemokines/ chemoattractants known to preferentially attract effector lymphocytes, including CXCR3 ligands as well as $\mathrm{CX}_{3} \mathrm{CL} 1$ and chemerin, was shown to positively affect the antitumor nature of tumor-infiltrating lymphocytes with a large proportion of NK cells (88-91). Nevertheless, high concentrations of attracting chemokines do not always imply increased NK cell migration, as shown by Halama and coworkers in colorectal cancer tissue where $\mathrm{NKp} 46^{+} \mathrm{NK}$ cells are poorly infiltrated, despite high local chemokine levels (92).

An alternative and highly novel strategy to improve NK cell migration to target tissues is to promote or optimize the expression of chemoattractant receptors on NK cells to be used

\section{REFERENCES}

1. Yokoyama WM, Kim S, French AR. The dynamic life of natural killer cells. Annu Rev Immunol (2004) 22:405-29. doi:10.1146/annurev. immunol.22.012703.104711

2. Gajewski TF, Fuertes M, Spaapen R, Zheng Y, Kline J. Molecular profiling to identify relevant immune resistance mechanisms in the tumor microenvironment. Curr Opin Immunol (2011) 23(2):286-92. doi:10.1016/ j.coi.2010.11.013

3. Zlotnik A, Yoshie O. The chemokine superfamily revisited. Immunity (2012) 36(5):705-16. doi:10.1016/j.immuni.2012.05.008

4. Sojka DK, Tian Z, Yokoyama WM. Tissue-resident natural killer cells and their potential diversity. Semin Immunol (2014) 26(2):127-31. doi:10.1016/ j.smim.2014.01.010

5. Bernardini G, Sciume G, Santoni A. Differential chemotactic receptor requirements for NK cell subset trafficking into bone marrow. Front Immunol (2013) 4:12. doi:10.3389/fimmu.2013.00012

6. Gregoire C, Chasson L, Luci C, Tomasello E, Geissmann F, Vivier E, et al. The trafficking of natural killer cells. Immunol Rev (2007) 220:169-82. doi:10.1111/j.1600-065X.2007.00563.x

7. Mantovani A. The chemokine system: redundancy for robust outputs. Immunol Today (1999) 20(6):254-7. doi:10.1016/S0167-5699(99)01469-3

8. Cooper MA, Fehniger TA, Caligiuri MA. The biology of human natural killer-cell subsets. Trends Immunol (2001) 22(11):633-40. doi:10.1016/ S1471-4906(01)02060-9

9. Chan A, Hong DL, Atzberger A, Kollnberger S, Filer AD, Buckley CD, et al. CD56bright human NK cells differentiate into CD56dim cells: role of contact with peripheral fibroblasts. J Immunol (2007) 179(1):89-94. doi:10.4049/ jimmunol.179.1.89 for adoptive immunotherapy. The expression of chemokine receptors and the corresponding NK cell chemotactic response can be modulated upon cytokine-mediated activation thus suggesting that they may better home to tumor sites where their corresponding ligands are expressed (93-96). In addition, NK cells ex vivo engineered to express chemokine receptors by gene transfer or by trogocytosis are under investigation for their better tissue homing and function (97-101). Conversely, a number of new clinical trials for immune-mediated diseases based on the use of chemokine receptor antagonists are ongoing and will help to understand the therapeutic potential of these important targets for NK cell-promoted pathologies (102). Finally, the emerging role of chemoattractant receptor interplay in the regulation of immune cell response may also lead to the discovery of molecules able to block chemokine receptor cross-inhibition thus allowing to unleash the full chemotactic potential of important NK cell receptors, such as CXCR4.

\section{AUTHOR CONTRIBUTIONS}

GB, FA, VB, and AS contributed equally to writing and critically revised the paper.

\section{FUNDING}

The authors' research activities are supported by grants from the Italian Association for Cancer Research (AIRC: project \#16014 and AIRC 5xmille: project \#9962), Istituto Pasteur-Fondazione Cenci Bolognetti, and Ministero dell'Istruzione, dell'Università e della Ricerca (PRIN: project \#PRIN20103 FMJEN and PRIN 2010 C2LKKJ-003).

10. Ouyang Q, Baerlocher G, Vulto I, Lansdorp PM. Telomere length in human natural killer cell subsets. Ann N Y Acad Sci (2007) 1106:240-52. doi:10.1196/ annals. 1392.001

11. Romagnani C, Juelke K, Falco M, Morandi B, D’Agostino A, Costa R, et al. CD56brightCD16- killer Ig-like receptor- NK cells display longer telomeres and acquire features of CD56dim NK cells upon activation. J Immunol (2007) 178(8):4947-55. doi:10.4049/jimmunol.178.8.4947

12. Huntington ND, Legrand N, Alves NL, Jaron B, Weijer K, Plet A, et al. IL-15 trans-presentation promotes human NK cell development and differentiation in vivo. J Exp Med (2009) 206(1):25-34. doi:10.1084/jem.20082013

13. Berahovich RD, Lai NL, Wei Z, Lanier LL, Schall TJ. Evidence for NK cell subsets based on chemokine receptor expression. J Immunol (2006) 177(11):7833-40. doi:10.4049/jimmunol.177.11.7833

14. Campbell JJ, Qin S, Unutmaz D, Soler D, Murphy KE, Hodge MR, et al. Unique subpopulations of CD56+ NK and NK-T peripheral blood lymphocytes identified by chemokine receptor expression repertoire. J Immunol (2001) 166(11):6477-82. doi:10.4049/jimmunol.166.11.6477

15. Fehniger TA, Cooper MA, Nuovo GJ, Cella M, Facchetti F, Colonna M, et al. CD56bright natural killer cells are present in human lymph nodes and are activated by $\mathrm{T}$ cell-derived IL-2: a potential new link between adaptive and innate immunity. Blood (2003) 101(8):3052-7. doi:10.1182/ blood-2002-09-2876

16. Parolini S, Santoro A, Marcenaro E, Luini W, Massardi L, Facchetti F, et al. The role of chemerin in the colocalization of $\mathrm{NK}$ and dendritic cell subsets into inflamed tissues. Blood (2007) 109(9):3625-32. doi:10.1182/ blood-2006-08-038844

17. Stabile H, Nisti P, Morrone S, Pagliara D, Bertaina A, Locatelli F, et al. Multifunctional human CD56 low CD16 low natural killer cells are the prominent subset in bone marrow of both healthy pediatric donors and 
leukemic patients. Haematologica (2015) 100(4):489-98. doi:10.3324/ haematol.2014.116053

18. Vitale M, Della Chiesa M, Carlomagno S, Romagnani C, Thiel A, Moretta L, et al. The small subset of CD56brightCD16- natural killer cells is selectively responsible for both cell proliferation and interferon-gamma production upon interaction with dendritic cells. Eur J Immunol (2004) 34(6):1715-22. doi:10.1002/eji.200425100

19. Lanier LL, Le AM, Phillips JH, Warner NL, Babcock GF. Subpopulations of human natural killer cells defined by expression of the Leu-7 (HNK-1) and Leu-11 (NK-15) antigens. J Immunol (1983) 131(4):1789-96.

20. Juelke K, Killig M, Luetke-Eversloh M, Parente E, Gruen J, Morandi B, et al. CD62L expression identifies a unique subset of polyfunctional CD56dim NK cells. Blood (2010) 116(8):1299-307. doi:10.1182/blood-2009-11-253286

21. Lopez-Verges S, Milush JM, Pandey S, York VA, Arakawa-Hoyt J, Pircher H, et al. CD57 defines a functionally distinct population of mature NK cells in the human CD56dimCD16+ NK-cell subset. Blood (2010) 116(19):3865-74. doi:10.1182/blood-2010-04-282301

22. Chiossone L, Chaix J, Fuseri N, Roth C, Vivier E, Walzer T. Maturation of mouse NK cells is a 4-stage developmental program. Blood (2009) 113(22):5488-96. doi:10.1182/blood-2008-10-187179

23. Hayakawa Y, Huntington ND, Nutt SL, Smyth MJ. Functional subsets of mouse natural killer cells. Immunol Rev (2006) 214:47-55. doi:10.1111/j.1600-065X.2006.00454.x

24. Huntington ND, Tabarias H, Fairfax K, Brady J, Hayakawa Y, Degli-Esposti $\mathrm{MA}$, et al. NK cell maturation and peripheral homeostasis is associated with KLRG1 up-regulation. J Immunol (2007) 178(8):4764-70. doi:10.4049/ jimmunol.178.8.4764

25. Sciume G, De Angelis G, Benigni G, Ponzetta A, Morrone S, Santoni A, et al. CX3CR1 expression defines 2 KLRG1+ mouse NK-cell subsets with distinct functional properties and positioning in the bone marrow. Blood (2011) 117(17):4467-75. doi:10.1182/blood-2010-07-297101

26. Marquardt N, Wilk E, Pokoyski C, Schmidt RE, Jacobs R. Murine CXCR3+CD27bright NK cells resemble the human CD56bright NK-cell population. Eur J Immunol (2010) 40(5):1428-39. doi:10.1002/eji.200940056

27. Eisenhardt M, Glassner A, Kramer B, Korner C, Sibbing B, Kokordelis P, et al. The CXCR3(+)CD56Bright phenotype characterizes a distinct NK cell subset with anti-fibrotic potential that shows dys-regulated activity in hepatitis $\mathrm{C}$. PLoS One (2012) 7(7):e38846. doi:10.1371/journal.pone.0038846

28. Paust S, Gill HS, Wang BZ, Flynn MP, Moseman EA, Senman B, et al. Critical role for the chemokine receptor CXCR6 in NK cell-mediated antigen-specific memory of haptens and viruses. Nat Immunol (2010) 11(12):1127-35. doi:10.1038/ni.1953

29. Stegmann KA, Robertson F, Hansi N, Gill U, Pallant C, Christophides T, et al. CXCR6 marks a novel subset of T-bet(lo)Eomes(hi) natural killer cells residing in human liver. Sci Rep (2016) 6:26157. doi:10.1038/srep26157

30. Broxmeyer HE, Kim CH. Regulation of hematopoiesis in a sea of chemokine family members with a plethora of redundant activities. Exp Hematol (1999) 27(7):1113-23. doi:10.1016/S0301-472X(99)00045-4

31. Zabel BA, Rott A, Butcher EC. Leukocyte chemoattractant receptors in human disease pathogenesis. Annu Rev Pathol (2015) 10:51-81. doi:10.1146/ annurev-pathol-012513-104640

32. Campbell JJ, Foxman EF, Butcher EC. Chemoattractant receptor cross talk as a regulatory mechanism in leukocyte adhesion and migration. Eur J Immunol (1997) 27(10):2571-8. doi:10.1002/eji.1830271016

33. Foxman EF, Kunkel EJ, Butcher EC. Integrating conflicting chemotactic signals. The role of memory in leukocyte navigation. JCell Biol (1999) 147(3):577-88. doi:10.1083/jcb.147.3.577

34. Ali H, Richardson RM, Haribabu B, Snyderman R. Chemoattractant receptor cross-desensitization. J Biol Chem (1999) 274(10):6027-30. doi:10.1074/ jbc.274.10.6027

35. Martin C, Burdon PC, Bridger G, Gutierrez-Ramos JC, Williams TJ, Rankin SM. Chemokines acting via CXCR2 and CXCR4 control the release of neutrophils from the bone marrow and their return following senescence. Immunity (2003) 19(4):583-93. doi:10.1016/S1074-7613(03)00263-2

36. Bernardini G, Sciume G, Bosisio D, Morrone S, Sozzani S, Santoni A. CCL3 and CXCL12 regulate trafficking of mouse bone marrow NK cell subsets. Blood (2008) 111(7):3626-34. doi:10.1182/blood-2007-08-106203
37. Ponzetta A, Sciume G, Benigni G, Antonangeli F, Morrone S, Santoni A, et al. CX3CR1 regulates the maintenance of KLRG1+ NK cells into the bone marrow by promoting their entry into circulation. J Immunol (2013) 191(11):5684-94. doi:10.4049/jimmunol.1300090

38. Mayol K, Biajoux V, Marvel J, Balabanian K, Walzer T. Sequential desensitization of CXCR4 and S1P5 controls natural killer cell trafficking. Blood (2011) 118(18):4863-71. doi:10.1182/blood-2011-06-362574

39. Ponzetta A, Benigni G, Antonangeli F, Sciume G, Sanseviero E, Zingoni A, et al. Multiple myeloma impairs bone marrow localization of effector natural killer cells by altering the chemokine microenvironment. Cancer Res (2015) 75(22):4766-77. doi:10.1158/0008-5472.CAN-15-1320

40. Vischer HF, Watts AO, Nijmeijer S, Leurs R. G protein-coupled receptors: walking hand-in-hand, talking hand-in-hand? Br JPharmacol (2011) 163(2):246-60. doi:10.1111/j.1476-5381.2011.01229.x

41. Kramp BK, Sarabi A, Koenen RR, Weber C. Heterophilic chemokine receptor interactions in chemokine signaling and biology. Exp Cell Res (2011) 317(5):655-63. doi:10.1016/j.yexcr.2010.11.014

42. Contento RL, Molon B, Boularan C, Pozzan T, Manes S, Marullo S, et al. CXCR4-CCR5: a couple modulating T cell functions. Proc Natl Acad Sci U S A (2008) 105(29):10101-6. doi:10.1073/pnas.0804286105

43. Sohy D, Yano H, de Nadai P, Urizar E, Guillabert A, Javitch JA, et al. Hetero-oligomerization of CCR2, CCR5, and CXCR4 and the protean effects of "selective" antagonists. J Biol Chem (2009) 284(45):31270-9. doi:10.1074/ jbc.M109.054809

44. Watts AO, van Lipzig MM, Jaeger WC, Seeber RM, van Zwam M, Vinet J, et al. Identification and profiling of CXCR3-CXCR4 chemokine receptor heteromer complexes. Br J Pharmacol (2013) 168(7):1662-74. doi:10.1111/ bph. 12064

45. Bradfield PF, Amft N, Vernon-Wilson E, Exley AE, Parsonage G, Rainger GE, et al. Rheumatoid fibroblast-like synoviocytes overexpress the chemokine stromal cell-derived factor 1 (CXCL12), which supports distinct patterns and rates of $\mathrm{CD} 4+$ and $\mathrm{CD} 8+\mathrm{T}$ cell migration within synovial tissue. Arthritis Rheum (2003) 48(9):2472-82. doi:10.1002/art.11219

46. O'Boyle G, Fox CR, Walden HR, Willet JD, Mavin ER, Hine DW, et al. Chemokine receptor CXCR3 agonist prevents human T-cell migration in a humanized model of arthritic inflammation. Proc Natl Acad Sci U S A (2012) 109(12):4598-603. doi:10.1073/pnas.1118104109

47. Vanbervliet B, Bendriss-Vermare N, Massacrier C, Homey B, de Bouteiller O, Briere F, et al. The inducible CXCR3 ligands control plasmacytoid dendritic cell responsiveness to the constitutive chemokine stromal cell-derived factor 1 (SDF-1)/CXCL12. J Exp Med (2003) 198(5):823-30. doi:10.1084/ jem.20020437

48. Hanna J, Wald O, Goldman-Wohl D, Prus D, Markel G, Gazit R, et al. CXCL12 expression by invasive trophoblasts induces the specific migration of CD16- human natural killer cells. Blood (2003) 102(5):1569-77. doi:10.1182/ blood-2003-02-0517

49. Krug A, Uppaluri R, Facchetti F, Dorner BG, Sheehan KC, Schreiber RD, et al. IFN-producing cells respond to CXCR3 ligands in the presence of CXCL12 and secrete inflammatory chemokines upon activation. J Immunol (2002) 169(11):6079-83. doi:10.4049/jimmunol.169.11.6079

50. Nagasawa T. CXCL12/SDF-1 and CXCR4. Front Immunol (2015) 6:301. doi:10.3389/fimmu.2015.00301

51. Pablos JL, Amara A, Bouloc A, Santiago B, Caruz A, Galindo M, et al. Stromal-cell derived factor is expressed by dendritic cells and endothelium in human skin. Am J Pathol (1999) 155(5):1577-86. doi:10.1016/ S0002-9440(10)65474-0

52. Petit I, Szyper-Kravitz M, Nagler A, Lahav M, Peled A, Habler L, et al. G-CSF induces stem cell mobilization by decreasing bone marrow SDF-1 and up-regulating CXCR4. Nat Immunol (2002) 3(7):687-94. doi:10.1038/ni813

53. Stumm R, Culmsee C, Schafer MK, Krieglstein J, Weihe E. Adaptive plasticity in tachykinin and tachykinin receptor expression after focal cerebral ischemia is differentially linked to gabaergic and glutamatergic cerebrocortical circuits and cerebrovenular endothelium. J Neurosci (2001) 21(3):798-811.

54. Tham TN, Lazarini F, Franceschini IA, Lachapelle F, Amara A, Dubois-Dalcq M. Developmental pattern of expression of the alpha chemokine stromal cell-derived factor 1 in the rat central nervous system. Eur J Neurosci (2001) 13(5):845-56. doi:10.1046/j.0953-816x.2000.01451.x 
55. Castriconi R, Dondero A, Bellora F, Moretta L, Castellano A, Locatelli F, et al. Neuroblastoma-derived TGF-betal modulates the chemokine receptor repertoire of human resting NK cells. J Immunol (2013) 190(10):5321-8. doi:10.4049/jimmunol.1202693

56. Carrega P, Morandi B, Costa R, Frumento G, Forte G, Altavilla G, et al. Natural killer cells infiltrating human nonsmall-cell lung cancer are enriched in CD56 bright CD16(-) cells and display an impaired capability to kill tumor cells. Cancer (2008) 112(4):863-75. doi:10.1002/cncr.23239

57. Carrega P, Bonaccorsi I, Di Carlo E, Morandi B, Paul P, Rizzello V, et al. CD56(bright)perforin(low) noncytotoxic human NK cells are abundant in both healthy and neoplastic solid tissues and recirculate to secondary lymphoid organs via afferent lymph. J Immunol (2014) 192(8):3805-15. doi:10.4049/jimmunol.1301889

58. El-Sherbiny YM, Kelly RJ, Hill A, Doody GM, Hillmen P, Cook GP. Altered natural killer cell subset homeostasis and defective chemotactic responses in paroxysmal nocturnal hemoglobinuria. Blood (2013) 122(11):1887-90. doi:10.1182/blood-2013-06-507574

59. Szpurka H, Schade AE, Jankowska AM, Maciejewski JP. Altered lipid raft composition and defective cell death signal transduction in glycosylphosphatidylinositol anchor-deficient PIG-A mutant cells. Br J Haematol (2008) 142(3):413-22. doi:10.1111/j.1365-2141.2008.07203.x

60. Mace EM, Hsu AP, Monaco-Shawver L, Makedonas G, Rosen JB, Dropulic L, et al. Mutations in GATA2 cause human NK cell deficiency with specific loss of the CD56(bright) subset. Blood (2013) 121(14):2669-77. doi:10.1182/ blood-2012-09-453969

61. Clift IC, Bamidele AO, Rodriguez-Ramirez C, Kremer KN, Hedin KE. beta-Arrestin 1 and distinct CXCR4 structures are required for stromal derived factor-1 to downregulate CXCR4 cell-surface levels in neuroblastoma. Mol Pharmacol (2014) 85(4):542-52. doi:10.1124/mol.113.089714

62. Gomez-Mouton C, Fischer T, Peregil RM, Jimenez-Baranda S, Stossel TP, Nakamura F, et al. Filamin A interaction with the CXCR4 third intracellular loop regulates endocytosis and signaling of WT and WHIM-like receptors. Blood (2015) 125(7):1116-25. doi:10.1182/blood-2014-09-601807

63. Maciejewski-Duval A, Meuris F, Bignon A, Aknin ML, Balabanian K, Faivre L, et al. Altered chemotactic response to CXCL12 in patients carrying GATA2 mutations. JLeukoc Biol (2016) 99(6):1065-76. doi:10.1189/ jlb.5MA0815-388R

64. Gulino AV, Moratto D, Sozzani S, Cavadini P, Otero K, Tassone L, et al. Altered leukocyte response to CXCL12 in patients with warts hypogammaglobulinemia, infections, myelokathexis (WHIM) syndrome. Blood (2004) 104(2):444-52. doi:10.1182/blood-2003-10-3532

65. Balabanian K, Lagane B, Pablos JL, Laurent L, Planchenault T, Verola O, et al. WHIM syndromes with different genetic anomalies are accounted for by impaired CXCR4 desensitization to CXCL12. Blood (2005) 105(6):2449-57. doi:10.1182/blood-2004-06-2289

66. Doncker AV, Balabanian K, Bellanne-Chantelot C, de Guibert S, Revest M, Bachelerie F, et al. Two cases of disseminated Mycobacterium avium infection associated with a new immunodeficiency syndrome related to CXCR4 dysfunctions. Clin Microbiol Infect (2011) 17(2):135-9. doi:10.1111/j.1469-0691.2010.03187.x

67. Calderon TM, Eugenin EA, Lopez L, Kumar SS, Hesselgesser J, Raine CS, et al. A role for CXCL12 (SDF-1alpha) in the pathogenesis of multiple sclerosis: regulation of CXCL12 expression in astrocytes by soluble myelin basic protein. JNeuroimmunol (2006) 177(1-2):27-39. doi:10.1016/ j.jneuroim.2006.05.003

68. Krumbholz M, Theil D, Cepok S, Hemmer B, Kivisakk P, Ransohoff RM, et al. Chemokines in multiple sclerosis: CXCL12 and CXCL13 upregulation is differentially linked to CNS immune cell recruitment. Brain (2006) 129(Pt 1):200-11. doi:10.1093/brain/awh680

69. Serrano-Pertierra E, Blanco-Gelaz MA, Oliva-Nacarino P, MartinezCamblor P, Villafani J, Lopez-Larrea C, et al. Increased natural killer cell chemotaxis to CXCL12 in patients with multiple sclerosis. J Neuroimmunol (2015) 282:39-44. doi:10.1016/j.jneuroim.2015.03.007

70. Lunemann JD, Munz C. Do natural killer cells accelerate or prevent autoimmunity in multiple sclerosis? Brain (2008) 131(Pt 7):1681-3. doi:10.1093/ brain/awn132

71. Kastrukoff LF, Lau A, Wee R, Zecchini D, White R, Paty DW. Clinical relapses of multiple sclerosis are associated with 'novel' valleys in natural killer cell functional activity. J Neuroimmunol (2003) 145(1-2):103-14. doi:10.1016/ j.jneuroim.2003.10.001

72. Bielekova B, Catalfamo M, Reichert-Scrivner S, Packer A, Cerna M, Waldmann TA, et al. Regulatory CD56(bright) natural killer cells mediate immunomodulatory effects of IL-2Ralpha-targeted therapy (daclizumab) in multiple sclerosis. Proc Natl Acad Sci U S A (2006) 103(15):5941-6. doi: $10.1073 /$ pnas.0601335103

73. Rodriguez-Martin E, Picon C, Costa-Frossard L, Alenda R, Sainz de la Maza $\mathrm{S}$, Roldan E, et al. Natural killer cell subsets in cerebrospinal fluid of patients with multiple sclerosis. Clin Exp Immunol (2015) 180(2):243-9. doi:10.1111/ cei. 12580

74. Vandenbark AA, Huan J, Agotsch M, La Tocha D, Goelz S, Offner H, et al. Interferon-beta-1a treatment increases CD56bright natural killer cells and CD4+CD25+ Foxp3 expression in subjects with multiple sclerosis. J Neuroimmunol (2009) 215(1-2):125-8. doi:10.1016/j.jneuroim.2009.08.007

75. Martinez-Rodriguez JE, Lopez-Botet M, Munteis E, Rio J, Roquer J, Montalban X, et al. Natural killer cell phenotype and clinical response to interferon-beta therapy in multiple sclerosis. Clin Immunol (2011) 141(3):348-56. doi:10.1016/j.clim.2011.09.006

76. Martin-Fontecha A, Thomsen LL, Brett S, Gerard C, Lipp M, Lanzavecchia A et al. Induced recruitment of NK cells to lymph nodes provides IFN-gamma for $\mathrm{T}(\mathrm{H}) 1$ priming. Nat Immunol (2004) 5(12):1260-5. doi:10.1038/ni1138

77. Pak-Wittel MA, Yang L, Sojka DK, Rivenbark JG, Yokoyama WM. Interferongamma mediates chemokine-dependent recruitment of natural killer cells during viral infection. Proc Natl Acad Sci U S A (2013) 110(1):E50-9. doi:10.1073/pnas.1220456110

78. Watt SV, Andrews DM, Takeda K, Smyth MJ, Hayakawa Y. IFN-gammadependent recruitment of mature CD27(high) NK cells to lymph nodes primed by dendritic cells. J Immunol (2008) 181(8):5323-30. doi:10.4049/ jimmunol.181.8.5323

79. Wendel M, Galani IE, Suri-Payer E, Cerwenka A. Natural killer cell accumulation in tumors is dependent on IFN-gamma and CXCR3 ligands. Cancer Res (2008) 68(20):8437-45. doi:10.1158/0008-5472.CAN-08-1440

80. Bolomsky A, Schreder M, Hubl W, Zojer N, Hilbe W, Ludwig H. Monokine induced by interferon gamma (MIG/CXCL9) is an independent prognostic factor in newly diagnosed myeloma. Leuk Lymphoma (2016) 21:1-10. doi:10.3109/10428194.2016.1151511

81. Riva A, Laird M, Casrouge A, Ambrozaitis A, Williams R, Naoumov NV, et al. Truncated CXCL10 is associated with failure to achieve spontaneous clearance of acute hepatitis C infection. Hepatology (2014) 60(2):487-96. doi:10.1002/hep.27139

82. Ishibashi H, Shimoda S. [Pathogenesis of biliary tract injury in primary biliary cirrhosis]. Nihon Rinsho Meneki Gakkai Kaishi (2012) 35(6):455-62. doi: $10.2177 /$ jsci.35.455

83. Chuang YH, Lian ZX, Cheng CM, Lan RY, Yang GX, Moritoki Y, et al. Increased levels of chemokine receptor CXCR3 and chemokines IP-10 and MIG in patients with primary biliary cirrhosis and their first degree relatives. J Autoimmun (2005) 25(2):126-32. doi:10.1016/j.jaut.2005.08.009

84. Gao B, Bertola A. Natural killer cells take two tolls to destruct bile ducts. Hepatology (2011) 53(4):1076-9. doi:10.1002/hep.24275

85. Shimoda S, Selmi C, Gershwin ME. Fractalkine and other chemokines in primary biliary cirrhosis. Int J Hepatol (2012) 2012:102839. doi:10.1155/ 2012/102839

86. Ottaviani C, Nasorri F, Bedini C, de Pita O, Girolomoni G, Cavani A. CD56brightCD16(-) NK cells accumulate in psoriatic skin in response to CXCL10 and CCL5 and exacerbate skin inflammation. Eur J Immunol (2006) 36(1):118-28. doi:10.1002/eji.200535243

87. Nakashima Y, Sun DH, Trindade MC, Chun LE, Song Y, Goodman SB, et al. Induction of macrophage $\mathrm{C}-\mathrm{C}$ chemokine expression by titanium alloy and bone cement particles. J Bone Joint Surg Br (1999) 81(1):155-62. doi:10.1302/0301-620X.81B1.8884

88. Ju DW, Tao Q, Cheng DS, Zhang W, Zhang M, Hamada H, et al. Adenovirusmediated lymphotactin gene transfer improves therapeutic efficacy of cytosine deaminase suicide gene therapy in established murine colon carcinoma. Gene Ther (2000) 7(4):329-38. doi:10.1038/sj.gt.3301082

89. Lode HN, Xiang R, Dreier T, Varki NM, Gillies SD, Reisfeld RA. Natural killer cell-mediated eradication of neuroblastoma metastases to bone marrow by targeted interleukin-2 therapy. Blood (1998) 91(5):1706-15. 
90. Nokihara H, Yanagawa H, Nishioka Y, Yano S, Mukaida N, Matsushima K, et al. Natural killer cell-dependent suppression of systemic spread of human lung adenocarcinoma cells by monocyte chemoattractant protein-1 gene transfection in severe combined immunodeficient mice. Cancer Res (2000) 60(24):7002-7.

91. Pachynski RK, Zabel BA, Kohrt HE, Tejeda NM, Monnier J, Swanson CD, et al. The chemoattractant chemerin suppresses melanoma by recruiting natural killer cell antitumor defenses. J Exp Med (2012) 209(8):1427-35. doi:10.1084/jem.20112124

92. Halama N, Braun M, Kahlert C, Spille A, Quack C, Rahbari N, et al. Natural killer cells are scarce in colorectal carcinoma tissue despite high levels of chemokines and cytokines. Clin Cancer Res (2011) 17(4):678-89. doi:10.1158/1078-0432.CCR-10-2173

93. Inngjerdingen $M$, Damaj B, Maghazachi AA. Expression and regulation of chemokine receptors in human natural killer cells. Blood (2001) 97(2):367-75. doi:10.1182/blood.V97.2.367

94. Mailliard RB, Alber SM, Shen H, Watkins SC, Kirkwood JM, Herberman RB, et al. IL-18-induced CD83+CCR7+ NK helper cells. J Exp Med (2005) 202(7):941-53. doi:10.1084/jem.20050128

95. Moustaki A, Argyropoulos KV, Baxevanis CN, Papamichail M, Perez SA. Effect of the simultaneous administration of glucocorticoids and IL-15 on human NK cell phenotype, proliferation and function. Cancer Immunol Immunother (2011) 60(12):1683-95. doi:10.1007/s00262-011-1067-6

96. Sechler JM, Barlic J, Grivel JC, Murphy PM. IL-15 alters expression and function of the chemokine receptor CX3CR1 in human NK cells. Cell Immunol (2004) 230(2):99-108. doi:10.1016/j.cellimm.2004.10.001

97. Burga RA, Nguyen T, Zulovich J, Madonna S, Ylisastigui L, Fernandes R, et al. Improving efficacy of cancer immunotherapy by genetic modification of natural killer cells. Cytotherapy (2016). doi:10.1016/j.jcyt.2016.05.018

98. Carlsten M, Levy E, Karambelkar A, Li L, Reger R, Berg M, et al. Efficient mRNA-based genetic engineering of human NK cells with high-affinity
CD16 and CCR7 augments rituximab-induced ADCC against lymphoma and targets NK cell migration toward the lymph node-associated chemokine CCL19. Front Immunol (2016) 7:105. doi:10.3389/fimmu.2016.00105

99. Marcenaro E, Cantoni C, Pesce S, Prato C, Pende D, Agaugue S, et al. Uptake of CCR7 and acquisition of migratory properties by human KIR+ NK cells interacting with monocyte-derived DC or EBV cell lines: regulation by KIR/HLA-class I interaction. Blood (2009) 114(19):4108-16. doi:10.1182/ blood-2009-05-222265

100. Muller N, Michen S, Tietze S, Topfer K, Schulte A, Lamszus K, et al. Engineering NK cells modified with an EGFRvIII-specific chimeric antigen receptor to overexpress CXCR4 improves immunotherapy of CXCL12/ SDF-1alpha-secreting glioblastoma. J Immunother (2015) 38(5):197-210. doi:10.1097/CJI.0000000000000082

101. Somanchi SS, Somanchi A, Cooper LJ, Lee DA. Engineering lymph node homing of ex vivo-expanded human natural killer cells via trogocytosis of the chemokine receptor CCR7. Blood (2012) 119(22):5164-72. doi:10.1182/ blood-2011-11-389924

102. Allegretti M, Cesta MC, Locati M. Allosteric modulation of chemoattractant receptors. Front Immunol (2016) 7:170. doi:10.3389/fimmu.2016.00170

Conflict of Interest Statement: The authors declare that the research was conducted in the absence of any commercial or financial relationships that could be construed as a potential conflict of interest.

Copyright (c) 2016 Bernardini, Antonangeli, Bonanni and Santoni. This is an open-access article distributed under the terms of the Creative Commons Attribution License (CC BY). The use, distribution or reproduction in other forums is permitted, provided the original author(s) or licensor are credited and that the original publication in this journal is cited, in accordance with accepted academic practice. No use, distribution or reproduction is permitted which does not comply with these terms. 